\title{
Analisis Pengaruh Partisipasi Anggaran Dan Informasi Asimetri Terhadap Senjangan Anggaran (Budgetary Slack) Pada Perguruan Tinggi Swasta Di Kabupaten Pamekasan
}

\author{
Ika Oktaviana Dewi* \\ Program Studi Akuntansi, Fakultas Ekonomi, Universitas Islam Madura \\ Jln. Pondok Pesantren Miftahul Ulum Bettet Pamekasan, 69351, Indonesia
}

\begin{abstract}
Someone's involvement in budgeting will create a budgetary slack. This article aims to analyze the effect of budgetary participation and information asymmetry on budgetary slack. This type of research includes quantitative research, the focus of which will be directed at budgetary participation and information asymmetry in private universities in Pamekasan. Furthermore, the data were analyzed using statistical tests such as data quality tests, classical assumption tests and hypothesis testing. The results showed that the first hypothesis was accepted, which means that there was a significant influence between budgetary participation and budgetary slack. For the second hypothesis it is also accepted that there is a significant influence between information asymmetry on budgetary slack. The third hypothesis is tested simultaneously, the results are budgetary participation and information asymmetry together can create a larger budgetary slack.
\end{abstract}

Keywords: Budget Participation, Information Asymmetry, Budgetary Slack, Private Universities, Pamekasan

Paper type: Research paper

*Corresponding author: ikaoktavianadewi18@gmail.com Received: 13 Oktober 2020, ; Accepted: 17 Juni 2021; Published: 30 Juni 2021

Cite this document: Dewi, I.O. (2021). Analisis Pengaruh Partisipasi Anggaran Dan Informasi Asimetri Terhadap Senjangan Anggaran (Budgetary Slack) Pada Perguruan Tinggi Swasta Di Kabupaten Pamekasan. BISEI: Jurnal Bisnis dan Ekonomi Islam,5(1), $38-49$

Copyright (C) 2021, BISEI: JurnalBisnis dan Ekonomi Islam http://ejournal.unhasy.ac.id/index.php/bisei 
Ika Oktaviana Dewi: Analisis Pengaruh Partisipasi Anggaran Dan Informasi Asimetri Terhadap Senjangan Anggaran (Budgetary Slack) Pada Perguruan Tinggi Swasta Di Kabupaten Pamekasan

Abstrak: Keterlibatan seseorang dalam penyusunan anggaran akan menciptakan sebuah senjangan anggaran. Artikel ini memiliki tujuan untuk menganalisis pengaruh partisipasi anggaran dan informasi asimetri terhadap senjangan anggaran. Jenis penelitian ini termasuk penelitian kuantitatif, yang fokus penelitiaannya akan diarahkan pada partisipasi anggaran dan informasi asimetri di Perguruan Tinggi Swasta yang ada di Pamekasan. Selanjutnya data tersebut dianalisis dengan menggunakan uji statistik seperti uji kualitas data, uji asumsi klasik dan uji hepotesis. Hasil dari penelitian menunjukkan bahwa hipotesis pertama diterima yang artinya terdapat pengaruh signifikan antara partisipasi anggaran dengan senjangan anggaran. Untuk hipotesis kedua juga diterima yaitu terdapat pengaruh signifikan antara informasi asimetri terhadap senjangan anggaran. Hipotesis ketiga di uji secara simultan yang hasilnya partisipasi anggaran dan informasi asimetri secara bersama-sama dapat menciptakan senjangan anggaran yang lebih besar.

Kata kunci: Partisipasi Anggaran, Informasi Asimetri, Senjangan Anggaran, Perguruan Tinggi Swasta, Pamekasan

\section{Pendahuluan}

Berlakunya Undang-Undang Republik Indonesia Nomor 12 Tahun 2012 Tentang Pendidikan Tinggi pada Bab I Pasal 1 ayat 2 menjelaskan bahwa pendidikan tinggi adalah jenjang pendidikan setelah pendidikan menengah yang mencakup program diploma, program sarjana, program magister, program doktor, dan program profesi, serta program spesialis, yang diselenggarakan oleh perguruan tinggi berdasarkan kebudayaan bangsa Indonesia. Selanjutnya pada pasal 1 ayat 7 dan 8 disebutkan bahwa Indonesia memiliki dua jenis perguruan tinggi, yaitu negeri dan swasta (Undang -Undang Republik Indonesia Nomor 12 Tahun 2012 Tentang Pendidikan Tinggi, 2012).

Bagian ketiga tentang pendirian perguruan tinggi dalam Undang-Undang Republik Indonesia Nomor 12 Tahun 2012 Tentang Pendidikan Tinggi Pendidikan Tinggi pada Pasal 60 ayat 2 dijelaskan bahwa PTS didirikan oleh Masyarakat dengan membentuk badan penyelenggara berbadan hukum yang berprinsip nirlaba dan wajib memperoleh izin Menteri (Undang -Undang Republik Indonesia Nomor 12 Tahun 2012 Tentang Pendidikan Tinggi, 2012). Oleh karena itu Perguruan Tinggi Swasta dituntut untuk dapat mengelola dengan baik perguruan tingginya serta berakuntabilitas, sehingga masyarakat percaya akan pertanggungjawaban yang dikelola oleh perguruan tinggi tersebut.

Anggaran merupakan pengendalian keuangan internal dan akuntabilitas suatu organisasi baik negara maupun swasta untuk mencapai tujuan organisasi (Rini \& Nie, 2016). Melalui anggaran perguruan tinggi swasta dapat mengukur sejauh mana pendapatan dan pengeluaran perguruan tinggi dalam satu tahun. Perguruan tinggi harus memiliki strategi untuk mencapai tujuan dan cita-citanya, dengan cara membuat strategi jangka pendek, menengah dan panjang yang dikemas dalam Renstra Perguruan Tinggi. Renstra tersebut digunakan sebagai alat penyusunan anggaran perguruan tinggi.

Penyusunan anggaran merupakan keterlibatan manajer dalam penyusunan anggaran untuk mencapai tujuan organisasi (Ingga, 2018). Penyusunan anggaran biasanya melibatkan beberapa pihak terkait dalam suatu organisasi, misalnya 
penyusunan dalam suatu perguruan tinggi melibatkan rektor, wakil rektor, anggota senat, kepala lembaga, kepala biro dan kepala unit lainnya yang berada dilingkungan perguruan tinggi tersebut, namun pada proses penyusunan tersebut terdapat masalah mengenai hubungan keagenan yang terjadi antara penyusun anggaran dengan yang mengesahkan anggaran, sehingga akan menciptakan senjangan anggaran.

Senjangan anggaran merupakan keterlibatan seseorang dalam penyusunan anggaran yang dengan sengaja melebihkan biaya dan mengurangi pendapatan(Yuhertiana, 2005). Hilton et al (2000:249) dalam (Prakoso, 2016) menyatakan tiga alasan utama manajer melakukan senjangan anggaran:

a) Orang-orang selalu percaya bahwa hasil pekerjaan mereka akan terlihat bagus di mata atasan jika mereka dapat mencapai anggaranya;

b) Budgetary slack selalu digunakan untuk mengatasi kondisi ketidakpastian, dimana mungkin ada kejadian yang tidak terduga, sehingga dengan budgetary slack tersebut manajer dapat melampaui atau mencapai anggaranya;

c) Rencana anggaran selalu dipotong dalam proses pengalokasian sumber daya.

Tujuan dilaksanakannya senjangan anggaran agar kinerja para manajer lebih terlihat bagus karena target yang ditentukan telah tercapai (Rahayu \& Laksmita, 2017). (Rahayu \& Laksmita, 2017) mengatakan bahwa terdapat pengaruh positif partisipasi anggaran terhadap senjangan anggaran, terdapat pengaruh positip keterlibatan kerja terhadap senjangan anggaran.

Informasi Asimetri merupakan salah satu faktor terjadinya senjangan anggaran, seperti yang di sampaikan oleh (Suartana, 2010) bahwa informasi asimetri akan membuat senjagan lebih besar karena bawahan/eksekutif memiliki informasi yang lebih luas mengenai apa yang dimiliki oleh organisasi itu sendiri. Jadi informasi asimetri berpengaruh terhadap senjangan anggaran. (Rahayu \& Laksmita, 2017) dalam penelitiannya mengatakan bahwa informasi asimetri berpengaruh signifikan baik sebagai variabel independen maupun sebagai variabel moderasi.

Informasi asimetri merupakan keadaan, dimana antara atasan dengan bawahan memiliki informasi atau pengetahuan yang lebih luas (Suartana, 2010). Informasi yang bersifat asimetris akan menyulitkan salah satu pihak maupun keduanya, ketika atasan memiliki informasi yang lebih banyak dari bawahan makan target yang akan ditetapkan begitu besar, namun sebaliknya jika bawahan memeiliki pengetahuan yang lebih luas maka target yang akan ditentukan akan mudah tercapai.

Pengelolaan perguruan tinggi biasanya terdapat beberapa masalah terutama dalam anggaran, seperti 37 kasus yang diamati oleh Indonesia Corruption Watch (ICW), dia mengatakan bahwa 37 kasus tersebut pelakunya terdiri dari pejabat struktural di fakultas maupun universitas, pegawai pemerintah daerah dan pihak swasta. Kasus tersebut telah merugikan negara sebesar Rp 218.804 miliar, jumlah yang sangat besar. Motif dari kasus tersebut berupa pengadaan barang dan jasa, pembangunan infrasturktur, jual beli nilai, serta gratifikasi mahasiswa kepada dosen (Kukuh, 2016)

Copyright (C) 2021, BISEI: Jurnal Bisnis dan Ekonomi Islam http://ejournal.unhasy.ac.id/index.php/bisei 
Ika Oktaviana Dewi: Analisis Pengaruh Partisipasi Anggaran Dan Informasi Asimetri Terhadap Senjangan Anggaran (Budgetary Slack) Pada Perguruan Tinggi Swasta Di Kabupaten Pamekasan

Beberapa peneliti lain seperti (Basyir, 2016) disampaikan bahwa partisipasi anggaran dan informasi asimetri berpengaruh positif terhadap senjangan anggaran, (Ardianti et al., 2015) juga menyampaikan hal yang sama seperti bahwa partisipasi anggaran berpengaruh positif, sedangkan informasi asimetri tidak mampu memperkuat pengaruh partisipasi anggaran terhadap senjangan anggaran. Berdasarkan hasil penelitian dan kasus diatas dan pernyataan-pernyataan dari peneliti lain, maka penelitian tentang senjangan anggaran dilakukan kembali dengan obyek penelitian perguruan tinggi swasta di Pamekasan.

\section{Metode Penelitian}

Jenis penelitian ini adalah penelitian kuantitatif, karena penelitian ini menggunakan data berupa angka. (Siregar, 2017) menyatakan bahwa data kuantitatif adalah data berupa angka. Sumber data yang digunakan adalah data primer berupa data yang diperoleh melalui kuesioner yang disebar secara langsung kepada responden. Kuesioner yang disebar berupa daftar pernyataan mengenai partisipasi anggaran, informasi asimetri dan senjangan anggaran. Populasi adalah suatu wilayah generalisasi yang terdiri atas obyek/subyek yang mempunyai kualitas dan karakteristik tertentu yang dapat ditetapkan oleh peneliti untuk dipelajari dan kemudian dapat ditarik kesimpulannya (Sugiyono, 2016). Populasi pada penelitian ini adalah seluruh civitas akademika Perguruan Tinggi Swasta di Pamekasan. Sehingga, sampel dalam penelitian ini adalah manajemen Perguruan Tinggi Swasta yang terdiri dari top manager, midle manager dan low manager. Teknik pengambilan sampel yang digunakan adalah proportionate stratified random sampling. Sampel penelitian ditentukan dengan rumus Slovin, yaitu:

$$
n=\frac{N}{N(6)^{2} \mid 1}=\frac{156}{156(0,05)^{3}+1}=\frac{156}{1,39}=112
$$

Berdasarkan hasil perolehan diatas, maka sampel yang akan diteliti adalah 112 responden yang terdiri dari:

Tabel 1

Prosedur Pengambilan Sampel

\begin{tabular}{|l|c|c|}
\hline \multicolumn{1}{|c|}{ Keterangan } & Presentase Sampel & Jumlah Sampel \\
\hline Top Manager & $28 / 156 \times 100 \%=18 \%$ & $18 \% \times 112=20$ \\
\hline Midle Manager & $53 / 156 \times 100 \%=34 \%$ & $34 \% \times 112=38$ \\
\hline Low Manager & $75 / 156 \times 100 \%=48 \%$ & $48 \% \times 112=54$ \\
\hline \multicolumn{2}{|c|}{ Jumlah Sampel } & 112 Responden \\
\hline
\end{tabular}

Pengukuran variabel yang digunakan dilakukan dengan alat bantu kuesioner yang sudah diisi oleh responden. Pengukuran kuesioner pada penelitian ini menggunakan skala Likert yang dibuat dalam bentuk tabel. Kuesioner di uji menggunakan uji kualitas data dan uji asumsi klasik. Uji kualitas data meliputi uji validitas dan uji reliabilitas. Uji validitas merupakan instrumen yang dapat digunakan untuk mengukur data yang bisa menunjukan bahwa data tersebut valid (Ghozali, 2016). Suatu instrumen data dikatakan valid apabila r-hitung $>$ r-tabel 
atau nilai signifikansi $<0,05$. Uji reliabilitas merupakan suatu uji yang menunjukkan sejauh mana alat ukur suatu kuesioner dan hasil pengukuran indikator dari variabel (Ghozali, 2016). Suatu instrumen dikatakan reliabel apabila nilai Cronbach's Alpha $>0,70$. Setelah uji instrumen, uji yang selanjutnya adalah uji asumsi klasik yang meliputi uji normalitas, uji multikolinieritas dan uji heteroskedastisitas. Uji normalitas bertujuan untuk mengetahui apakah nilai residual berdistribusi normal atau tidak. Model regresi yang baik adalah yang memiliki nilai residual yang berdistribusi normal, dan syarat model regresi berdistribusi normal apabila nilai signifikansi $>0,05$. Uji multikolinieritas bertujuan untuk menguji apakah dalam model regresi ditemukan adanya korelasi antara variabel bebas. Model regresi yang baik seharusnya tidak terjadi korelasi antar variabel bebas. Kriteria pengukuran pada uji multikolinieritas apabila nilai tolerance $>10 \%(0,10)$ dan nilai VIF $<10$. Uji heteroskedastisitas bertujuan untuk mengetahui ada tidaknya kesamaan varian dari nilai residual untuk semua pengamatan pada model regresi. Untuk melihat ada tidaknya heteroskedastisitas adalah dengan menggunakan uji statistik berupa uji Glejser dan dilihat dengan grafik plot (scatterplot). Uji autokorelasi tidak dilakukan pada penelitian ini karena data yang digunakan bukan data time series.

Teknik analisis data pada penelitian ini menggunakan analisis regresi linear berganda yang dihitung dengan program SPSS. Analisis ini digunakan untuk menjawab bagaimana pengaruh Partisipasi Anggaran (X1) terhadap Senjangan Anggaran (Y) dan Informasi Asimetri (X2) terhadap Senjangan Anggaran (Y). Adapun persamaan regresi pada penelitian ini, yaitu:

$$
\mathrm{Y}=\alpha+\beta_{1} \mathrm{X}_{1}+\beta_{2} \mathrm{X}_{2}+\mathrm{e}
$$

Uji hipotesis yang digunakan pada penelitian ini adalah uji persial (uji T) dan uji simultan (uji F) serta Koefisien determinasi $\left(\mathrm{R}^{2}\right)$ yang bertujuan untuk mengukur seberapa jauh kemampuan mengenai model regresi dalam menerangkan variasi variabel terikat (Ghozali, 2016)

\section{Hasil dan Pembahasan Statistik Deskriptif}

Hasil analisis statistik deskriptif terhadap variabel yang digunakan pada penelitian ini disajikan pada tabel dibawah ini: 
Ika Oktaviana Dewi: Analisis Pengaruh Partisipasi Anggaran Dan Informasi Asimetri Terhadap Senjangan Anggaran (Budgetary Slack) Pada Perguruan Tinggi Swasta Di Kabupaten Pamekasan

Tabel 2

Deskripsi Variabel Partisipasi Anggaran, Informasi Asimetri dan senjangan Anggaran

\begin{tabular}{|l|c|c|c|c|c|}
\hline & $\mathrm{N}$ & Minimum & Maximum & Mean & Std. Deviation \\
\hline Partisipasi Anggaran & 112 & 20 & 45 & 37,027 & 5,669 \\
\hline Informasi Asimetri & 112 & 11 & 30 & 23,366 & 4,007 \\
\hline Senjangan Anggaran & 112 & 25 & 50 & 39,732 & 5,169 \\
\hline Valid N (listwise) & 112 & & & & \\
\hline
\end{tabular}

Dapat diketahui bahwa variabel partisipasi anggaran memiliki nilai minimum sebesar 20 dan nilai maksimum sebesar 45 dengan nilai rata-rata sebesar 37,027 dan standar deviasi sebesar 5,669, hal ini menunjukkan bahwa partisipasi responden penelitian tinggi dalam penyusunan anggaran. Variabel informasi asimetri memiliki nilai minimum sebesar 11 dan nilai maksimum sebesar 30 dengan nilai rata-rata sebesar 23,366 dan standar deviasi sebesar 4,007, hal ini menunjukkan bahwa informasi yang dimiliki bawahan lebih banyak dari informasi yang dimiliki atasannya dalam penyusunan anggaran. Variabel senjangan anggaran memiliki nilai minimum sebesar 25 dan nilai maksimum sebesar 50 dengan nilai rata-rata sebesar 39,732 dan standar deviasi sebesar 5,169, hal ini menunjukkan bahwa responden penelitian tidak melakukan senjangan anggaran.

\section{Uji Kualitas Data}

Sebelum melakukan uji hipotesis, terlebih dahulu yang dilakukan adalah uji kualitas data dan asumsi klasik. Uji kualitas data bertujuan untuk melihat seberapa baik data yang ada. Ketika data yang dimiliki tidak berkualitas maka data tersebut tidak dapat digunakan dan diolah karena akan mengakibatkan hasil uji hipotesis yang tidak benar. Uji kualitas data meliputi uji validitas dan uji reliabilitas.

\section{Uji Validitas}

Uji validitas merupakan instrumen yang dapat digunakan untuk mengukur data yang bisa menunjukan bahwa data tersebut valid (Ghozali, 2016). Tiap instrumen dikatakan valid apabila nilai korelasi r-hitung $>$ r-tabel (nilai $r$-tabel $=0,1840$ ). Nilai validitas dapat dilihat pada kolom pearson correlation.

Tabel 3

Uji Validitas

\begin{tabular}{|c|cc|c|c|}
\hline Variabel & \multicolumn{2}{|c|}{$\begin{array}{c}\text { Butiran } \\
\text { Instrumen }\end{array}$} & $\begin{array}{c}\text { Pearson } \\
\text { Correlation }\end{array}$ & Keterangan \\
\hline & 1. & PA_1 & 0,660 & Valid \\
& 2. & PA_2 & 0,744 & Valid \\
& 3. & PA_3 & 0,748 & Valid \\
Partisipasi & 4. & PA_4 & 0,800 & Valid \\
Anggaran & 5. & PA_5 & 0,825 & Valid \\
& 6. & PA_6 & 0,619 & Valid \\
& 7. & PA_7 & 0,667 & Valid \\
& 8. & PA_8 & 0,795 & Valid \\
& 9. & PA_9 & 0,694 & Valid \\
\hline
\end{tabular}




\begin{tabular}{|c|ll|l|l|}
\hline & 1. & IA_1 & 0,728 & Valid \\
Informasi & 2. & IA_2 & 0,818 & Valid \\
Asimetri & 3. & IA_3 & 0,689 & Valid \\
& 4. & IA_4 & 0,750 & Valid \\
& 5. & IA_5 & 0,698 & Valid \\
& 6. & IA_6 & 0,816 & Valid \\
\hline & 1. & SA_1 & 0,757 & Valid \\
& 2. & SA_2 & 0,665 & Valid \\
& 3. & SA_3 & 0,729 & Valid \\
& 4. & SA_4 & 0,506 & Valid \\
Senjangan & 5. & SA_5 & 0,675 & Valid \\
& 6. & SA_6 & 0,623 & Valid \\
& 7. & SA_7 & 0,690 & Valid \\
& 8. & SA_8 & 0,633 & Valid \\
& 9. & SA_9 & 6,476 & Valid \\
& 10. & SA_10 & 0,615 & Valid
\end{tabular}

Berdasarkan hasil uji validitas dapat disimpulkan bahwa seluruh item pertanyaan pada masing-masing variabel dinyatakan valid karena nilai korelasinya lebih besar dari 0,1840 .

\section{Uji Reliabilitas}

Uji reliabilitas merupakan suatu uji yang menunjukkan sejauh mana alat ukur suatu kuesioner dan hasil pengukuran indikator dari variabel (Ghozali, 2016). Tiap instrumen dikatakan reliabel apabila nilai Cronbach's Alpha $>0,70$.

\section{Tabel 4}

Uji Reliabilitas

\begin{tabular}{|l|c|c|}
\hline \multicolumn{1}{|c|}{ Variabel } & $\begin{array}{c}\text { Cronbach's } \\
\text { Alpha }\end{array}$ & Keterangan \\
\hline Partisipasi Anggaran & 0,889 & Reliabel \\
\hline Informasi Asimetri & 0,843 & Reliabel \\
\hline Senjangan Anggaran & 0,833 & Reliabel
\end{tabular}

Berdasarkan hasil uji reliabilitas dapat disimpulkan bahwa seluruh item pertanyaan pada masing-masing variabel dinyatakan reliabel karena nilai konsistensi koefisien Cronbach's Alpha berada di atas 0,70.

\section{Uji Asumsi Klasik}

Suatu model regresi linear berganda dikatakan baik apabila model regresi tersebut memenuhi syarat dari uji asumsi klasik yang terdiri dari uji normalitas, uji multikolinieritas dan uji heteroskedastisitas.

\section{Uji Normalitas}

Uji normalitas bertujuan untuk mengetahui apakah nilai residual berdistribusi normal atau tidak. Uji normalitas dapat dilakukan dengan dua cara yaitu analisis grafik dan uji statistik (Kolmogorov-Smirnov). Syarat suatu model regresi dikatakan berdistribusi normal apabila nilai signifikansi $>0,05$. 
Ika Oktaviana Dewi: Analisis Pengaruh Partisipasi Anggaran Dan Informasi Asimetri Terhadap Senjangan Anggaran (Budgetary Slack) Pada Perguruan Tinggi Swasta Di Kabupaten Pamekasan

Gambar 1

One-Sample Kolmogorov-Smirnov Test

\begin{tabular}{|ll|r|}
\hline & & \multicolumn{1}{|c|}{$\begin{array}{c}\text { Unstandardized } \\
\text { Residual }\end{array}$} \\
\hline $\mathrm{N}$ & & 112 \\
Normal Parameters & Mean &, 0000000 \\
& Std. Deviation & 3,62529809 \\
Most Extreme Differences & Absolute &, 100 \\
& Positive &, 042 \\
& Negative &,- 100 \\
Kolmogorov-Smirnov Z & & 1,058 \\
Asymp. Sig. (2-tailed) & &, 213 \\
\hline
\end{tabular}

a. Test distribution is Normal.

Dari hasil uji normalitas menyatakan bahwa nilai signifikansi sebesar 0,213 > 0,05 yang artinya data yang digunakan dalam penelitian ini berdistribusi normal dan bisa dilanjutkan untuk di teliti.

Gambar
Normal P-P Plot of Regression Standardized Residual

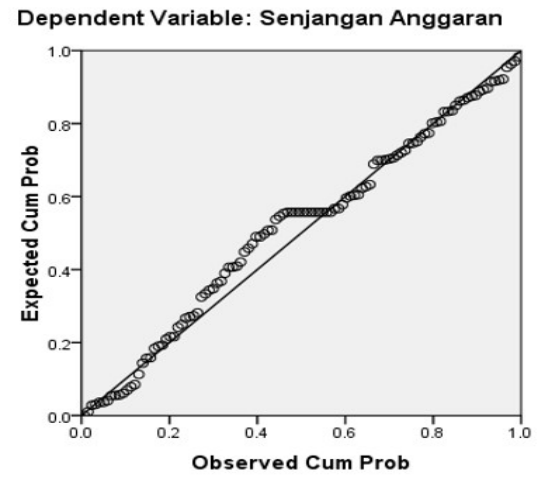

Uji Multikolinieritas

Uji ini bertujuan untuk menguji apakah dalam model regresi ditemukan adanya korelasi antara variabel bebas. Syarat pengukuran pada uji multikolinieritas adalah nilai tolerance $>10 \%(0,10)$ dan nilai VIF $<10$. Model regresi yang baik pada uji multikolinieritas adalah model yang tidak terjadi korelasi antara variabel bebas.

Gambar

Coefficients $^{a}$

\begin{tabular}{|c|c|c|c|c|c|c|c|c|}
\hline & \multirow{2}{*}{ Model } & \multicolumn{2}{|c|}{$\begin{array}{l}\text { Unstandardized } \\
\text { Coefficients }\end{array}$} & \multirow{2}{*}{$\begin{array}{c}\begin{array}{c}\text { Standardized } \\
\text { Coefficients }\end{array} \\
\text { Beta }\end{array}$} & \multirow{2}{*}{$\mathrm{t}$} & \multirow{2}{*}{ Sig. } & \multicolumn{2}{|c|}{$\begin{array}{l}\text { Collinearity } \\
\text { Statistics }\end{array}$} \\
\hline & & B & $\begin{array}{l}\text { Std. } \\
\text { Error }\end{array}$ & & & & Tolerance & VIF \\
\hline \multirow{3}{*}{1} & (Constant) & 15,138 & 2,361 & & 6,412 &, 000 & & \\
\hline & Partisipasi Anggaran & ,364 & 089 & ,400 & 4,109 &, 000 & ,477 & 2,096 \\
\hline & Informasi Asimetri & ,475 &, 125 & ,368 & 3,788 &, 000 & ,477 & 2,096 \\
\hline
\end{tabular}

a. Dependent Variable: Senjangan Anggaran

Berdasarkan hasil uji multikolinieritas dapat disimpulkan bahwa model regresi pada penelitian ini tidak terjadi kasus multikolinieritas, karena nilai tolerance 
lebih besar dari 0,10 yaitu $0,477>0,10$ dan nilai VIF $<10$ yaitu sebesar 2,096 < 10.

\section{Uji Heteroskedastisitas}

Uji heteroskedastisitas dilakukan dengan cara mengamati gambar grafik scatterplot yang ada dibawah ini:

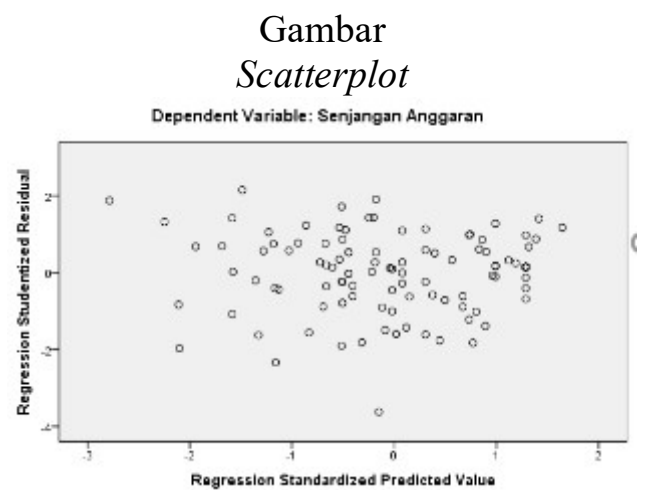

Berdasarkan hasil dari grafik scatterplot bahwa titik-titik penyebaran data tidak membentuk pola tertentu dan berada di atas maupun bawah angka 0 pada sumbu $\mathrm{Y}$, yang artinya model regresi tersebut tidak mengalami heteroskedastisitas.

\section{Uji Hipotesis}

Untuk hipotesis pertama dan kedua adalah hipotesis yang di uji secara persial antara variabel bebas dengan variabel terikat.

Coefficients $^{a}$

\begin{tabular}{|rl|r|r|r|r|r|}
\hline \multirow{2}{*}{ Model } & \multicolumn{2}{|c|}{$\begin{array}{c}\text { Unstandardized } \\
\text { Coefficients }\end{array}$} & $\begin{array}{c}\text { Standardized } \\
\text { Coefficients }\end{array}$ & \multirow{2}{*}{$\mathrm{t}$} & \multirow{2}{*}{ Sig. } \\
\cline { 2 - 5 } & \multicolumn{1}{|c|}{ B } & Std. Error & \multicolumn{1}{c|}{ Beta } & & \\
\hline \multirow{2}{*}{1} & (Constant) & 15,138 & 2,361 & & 6,412 &, 000 \\
& Partisipasi Anggaran &, 364 &, 089 &, 400 & 4,109 &, 000 \\
& Informasi Asimetri &, 475 &, 125 &, 368 & 3,788 &, 000 \\
\hline
\end{tabular}

1. Hipotesis pertama yaitu pengaruh partisipasi anggaran terhadap senjangan anggaran nilai signifikansi sebesar $0,000<0,05$ dan nilai t-hitung 4,109 $>$ ttabel 1,98197, sehingga dapat disimpulkan bahwa $\mathrm{H}_{0}$ ditolak dan $\mathrm{H}_{1}$ diterima.

2. Hipotesis kedua yaitu pengaruh informasi asimetri terhadap senjangan anggaran nilai signifikansi sebesar $0,000<0,05$ dan nilai t-hitung 3,788 $>$ ttabel 1,98197, sehingga dapat ditarik kesimpulan bahwa $\mathrm{H}_{0}$ ditolak dan $\mathrm{H}_{1}$ diterima.

\begin{tabular}{|ll|r|r|r|c|c|}
\hline Model & & Sum of Squares & \multicolumn{1}{c|}{ df } & Mean Square & F & Sig. \\
\hline 1 & Regression & 1507,115 & 2 & 753,558 & 56,303 &, $000^{\mathbf{a}}$ \\
& Residual & 1458,849 & 109 & 13,384 & & \\
& Total & 2965,964 & 111 & & & \\
\hline
\end{tabular}

a. Predictors: (Constant), Informasi Asimetri, Partisipasi Anggaran

b. Dependent Variable: Senjangan Anggaran 
Ika Oktaviana Dewi: Analisis Pengaruh Partisipasi Anggaran Dan Informasi

3. Untuk hipotesis ketiga di uji secara simultan antara variabel partisipasi anggaran dan informasi asimetri terhadap senjangan anggaran, dimana nilai signifikansi sebesar $0.000<0,05$ dan nilai f-hitung 56,303 $>3,07$ sehingga dapat ditarik kesimpulan bahwa $\mathrm{H}_{0}$ ditolak dan $\mathrm{H}_{1}$ diterima.

\section{Pengaruh Partisipasi Anggaran terhadap Senjangan Anggaran}

Berdasarkan hasil pengujian hipotesis menunjukkan bahwa $\mathrm{H}_{0}$ ditolak dan $\mathrm{H}_{1}$ diterima yang artinya bahwa partisipasi anggaran berpengaruh positif signifikan terhadap senjangan anggaran. Jadi semakin tinggi partisipasi anggaran maka semakin tinggi tingkat kesenjangan anggaran. Hal ini dimungkinkan terjadi karena ketika bawahan diikutsertakan menjadi partisipan dalam penyusunan anggaran, maka akan memberikan peluang bagi bawahan untuk menciptakan senjangan anggaran dan melonggarkan anggaran yang mereka susun agar anggaran yang mereka susun mudah dicapai. Penelitian ini mendukung penelitian yang dilakukan oleh (Wardani et al., 2014) yang menyatakan bahwa partisipasi anggaran secara signifikan mempengaruhi senjangan anggaran. Berbeda dengan penelitian yang dilakukan oleh (Ardanari \& Putra, 2014) yang menyatakan bahwa partisipasi anggaran berpengaruh negatif pada senjangan anggaran.

\section{Pengaruh Informasi Asimetri terhadap Senjangan Anggaran}

Hasil pengujian hipotesis menunjukkan bahwa $\mathrm{H}_{0}$ ditolak dan $\mathrm{H}_{2}$ diterima yang artinya bahwa informasi asimetri berpengaruh positif signifikan terhadap senjangan anggaran. Informasi asimetri akan membuat senjangan anggaran lebih besar karena bawahan memiliki informasi yang lebih luas dari pada atasannya mengenai apa yang dimiliki oleh organisasi itu sendiri (Suartana, 2010). Penelitian ini sejalan dengan penelitian yang dilakukan oleh (Rahayu \& Laksmita, 2017) yang dalam penelitiannya menyatakan bahwa informasi asimetri berpengaruh signifikan baik sebagai variabel independen maupun sebagai variabel moderasi. Berbeda hal dengan penelitian yang dilakukan oleh (Putranto, 2012) yang menyatakan bahwa informasi asimetri tidak mempengaruhi senjangan anggaran.

\section{Pengaruh Partisipasi Anggaran dan Informasi Asimetri terhadap Senjangan Anggaran}

Hasil pengujian hipotesis menyatakan bahwa $\mathrm{H}_{0}$ ditolak dan $\mathrm{H}_{3}$ diterima yang artinya secara bersama-sama partisipasi anggaran dan informasi asimetri berpengaruh signifikan terhadap senjangan anggaran. Hal ini dapat dilihat dari hasil nilai uji statistik f-hitung sebesar 56,303 > f-tabel sebesar 3,07 dengan nilai signifikansi sebesar $0,000<0,05$, yang artinya jika variabel partisipasi anggara dan informasi asimetri secara bersama-sama meningkat maka senjangan anggaran juga akan ikut meningkat.

\section{Penutup}

Penelitian ini bertujuan untuk mengetahui pengaruh partisipasi anggaran dan informasi asimetri terhadap senjangan anggaran. Berdasarkan hasil penelitian dan pembahasan dapat disimpulkan bahwa partisipasi anggaran berpengaruh positif 
signifikan terhadap senjangan anggaran. Informasi asimetri berpengaruh positif signifikan terhadap senjangan anggaran. Yang terakhir partisipasi anggaran dan informasi asimetri secara bersama-sama berpengaruh terhadap senjangan anggaran.

\section{Referensi}

Ardanari, I. G. A. A. S. C., \& Putra, I. N. W. A. (2014). Pengaruh pasrtisipasi peganggaran, asimetri informasi, self esteem dan budget emphasis pada budgetary slack. E-Jurnal Akuntansi Universitas Udayana, 3(2302-8556), $700-715$.

Ardianti, P. N. H., Suardikha, I. M. S., \& Suputra, I. D. G. D. (2015). Pengaruh Penganggaran Partisipatif Pada Budgetary Slack Dengan Asimetri Informasi, Self Esteem, Locus of Control Dan Kapasitas Individu Sebagai Variabel Moderasi (Studi Pada Skpd Kabupaten Jembrana, Bali). E-Jurnal Ekonomi Dan Bisnis Universitas Udayana, 4.05, 296-311.

Basyir, A. A. (2016). Pengaruh Partisipasi Anggaran, Informasi Asimetri, dan Kapasitas Individu terhadap Budgetary Slack pada SKPD PEMERINTAH KOTA SAMARINDA. AKUNTABEL: Jurnal Ekonomi Dan Keuangan, 13(2), 82-102. http://journal.feb.unmul.ac.id

Ghozali, I. (2016). Aplikasi Analisis Multivariate dengan Program IBM SPSS 23. Badan Penerbit Universitas Diponegoro.

Ingga, I. (2018). ANALISIS PENGARUH BUDGET PARTICIPATION DAN DECISION MAKING TERHADAP ORGANIZATIONAL COMMITMENT DAN MANAGERIAL PERFORMANCE. 02(02), 65-71.

Kukuh, T. (2016). Perguruan Tinggi Terbelit 37 Korupsi, Negara Rugi Rp 218,804 Miliar. https:/www.jawapos.com/nasional/hukumkriminal/30/10/2016/perguruan-tinggi-terbelit-37-korupsi-negara-rugi-rp218804-miliar

Undang -Undang Republik Indonesia Nomor 12 Tahun 2012 Tentang Pendidikan Tinggi, 661 (2012). https://doi.org/10.1017/CBO9781107415324.004

Prakoso, R. W. (2016). Analisis Pengaruh Partisipasi Anggaran, Informasi Asimetri, Komitmen Organisasi, dan Ketidakpastian Lingkungan terhadap Senjangan Anggaran: Studi Kasus pada SKPD Kota Semarang.

Putranto, Y. A. (2012). Pengaruh Moderasi Informasi Asimetri Dan Group Cohesiveness Terhadap Hubungan Partisipasi Penganggaran Dengan Budgetary Slack. Jurnal Economia, 8(2), 116-125. https://doi.org/10.21831/economia.v8i2.1221

Rahayu, I., \& Laksmita, G. (2017). Informasi asimetri dan senjangan anggaran pada perguruan tinggi di Yogyakarta. Jurnal Aplikasi Bisnis, 17(1), 60-76. https://doi.org/10.20885/jabis.vol17.iss1.art4

Rini, W. S., \& Nie, T. F. (2016). PENGARUH KOMITMEN ORGANISASI DAN KETIDAKPASTIAN LINGKUNGAN TERHADAP HUBUNGAN ANTARA PARTISIPASI ANGGARAN DENGAN SENJANGAN ANGGARAN PADA PERGURUAN TINGGI SWASTA DI BANJARMASIN. DINAMIKA EKONOMI Jurnal Ekonomi Dan Bisnis, 9(2), 
Ika Oktaviana Dewi: Analisis Pengaruh Partisipasi Anggaran Dan Informasi Asimetri Terhadap Senjangan Anggaran (Budgetary Slack) Pada Perguruan Tinggi Swasta Di Kabupaten Pamekasan

$172-191$.

Siregar, S. (2017). Metode Penelitian Kuantitatif Dilengkapi dengan Perbandingan Perhitungan Manual dan SPSS Versi 17. Jakarta: Kencana Persada Media Group. https://doi.org/10.1007/s12149-007-0126-8

Suartana, I. W. (2010). Akuntansi Keperilakuan (Teori dan Implementasi). CV Andi Offset.

Sugiyono. (2016). metodologi penelitian kuantitatif kualitatif dan R \& D. In Bandung: Alfabeta. https://doi.org/10.1164/rccm.200409-1267OC

Wardani, S. S., Vince, R., \& Rusli. (2014). Pengaruh Partisipasi Anggaran terhadap Senjangan Anggaran dengan Informasi Asimetri, Budaya Organisasi, Komitmen Organisasi,dan Ketidakpastian Lingkungan Sebagai Variabel Moderating (Studi Empiris Pada SKPD Kab. Pelalawan). JOM Fekon, 1(2), 1-20.

Yuhertiana, I. (2005). Kajian Etika Budgetary Slack Di Organisasi Sektor Publik Menurut Perspektif Gender". Simposium Riset Ekonomi II Surabaya, 23-24 November 2005. 